\section{ON THE OCCURRENCE OF AN INTERESTING LEAFLESS ORCHID NEOTTIA LISTEROIDES LINDL. in Himachal Pradesh, NORThWestern HIMALAYA, INDIA}

\author{
Jagdeep Verma ${ }^{1}$, Kranti Thakur ${ }^{2} \&$ S.P. Vij ${ }^{3}$
}

${ }^{1}$ Department of Botany, Shoolini Institute of Life Sciences and Business Management, Solan, Himachal Pradesh 173212, India

${ }^{2}$ Department of Botany, Shoolini University of Biotechnology and Management Sciences, Solan, Himachal Pradesh 173212, India

${ }^{3}$ Department of Botany, Panjab University, Chandigarh, Punjab 160014, India ${ }^{1}$ verma.jd@gmail.com (corresponding author), ${ }^{2}$ krantithakur1@gmail.com, ${ }^{3}$ spvij1@ rediffmail.com

The extensive orchid explorations from 2002-2010 in Himachal Pradesh, India have resulted in documenting many orchid species including some new distribution records. These orchids exhibit a variety of life forms (epiphytes/terrestrials/lithophytes) and are mostly distributed in the temperate hills. Five leafless terrestrial orchids, viz., Cymbidium macrorhizon Lindl., Epipogium aphyllum (F.W. Schmidt) Sw., E. roseum (D. Don) Lindl., Gastrodia falconeri D.L. Jones \& M.A. Clem. and Neottia listeroides Lindl. were found to occur in Himachal Pradesh. The present communication provides notes on taxonomy, distribution, habitat ecology and conservation of the interesting leafless species, Neottia listeroides.

The genus Neottia Guett. is derived from Greek word 'neottia' meaning 'the bird's nest' in allusion to their highly interwoven fibrous roots (Fig. 1a). The genus comprises of terrestrial leafless or leaf-bearing herbs that are widely distributed in Asia, Europe, and North America. Out of about 70 species worldwide (Xinqi et al. 2009), about 18 occur in India; only eight have been reported from northwestern Himalaya (Deva \& Naithani 1986; Jalal et al. 2008).

\section{Neottia listeroides}

Lindl. in Royle, III. Bot. Himal. Mts. 1: 368. 1839; Gen. Sp. Orch. PI. 458. 1840; Hook. f., Fl. Brit. India 6: 103. 1890; Collett, FI. Siml. 495. 1902; Seidenfaden \& Arora, Nordic J. Bot. 2: 21. 1982; Chowdhery \&

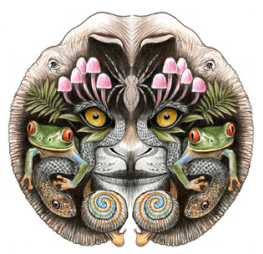

ISSN

Online 0974-7907 Print 0974-7893

\section{OPEN ACCESS} Wadhwa, Fl. Himachal Pradesh 3: 690. 1984; Deva \& Naithani, Orchid FI. N. W. Himalaya 71. t. 29. 1986. N. lindleyana Decne., in Jacquem. Voy. Bot. 163. t. 163. 1844. Listera lindleyana King \& Pantl., Ann. Roy. Bot. Gard. (Calcutta) 8: 258. t. 343. 1898; Duthie, Ann. Roy. Bot. Gard. (Calcutta) 9: 153. 1906.

Type: India, Mussoorie, Royle s.n. (holo, K.).

Terrestrial leafless herbs. Stem stout or slender, 10$30 \mathrm{~cm}$ long, 3-4 (-5) mm thick, base covered with 3-4 loose tubular sheaths, brownish-green, glabrous below, upper portion glandular-pubescent. Roots forming a congested mass at the base of stem, stout and brittle, c. 1-2 mm thick. Leaves absent. Racemes terminal, erect, $6-10 \mathrm{~cm}$ long, lax with many flowers. Floral bract small, ovate-lanceolate, c. 6-8×4-5 mm, sub acute, shorter than ovary. Flowers brownish-green or dark green, c. 8-12 mm long. Sepals subequal, elliptic-ovate, c. $5 \times 2.5 \mathrm{~mm}$, spreading, reflexed, subacute, the laterals somewhat falcate. Petals linear or more or less falcate, c. 5×1-1.5 mm. Lip brown, flat, narrowly obovate-oblong, 2-3 times longer than the lateral sepals, apex cleft into 2 oblong or lanceolate acute lobules, upper surface with a greenish linear groove, which forms a ridge on the back. Column curved, dilated at the base and apex, c. $3 \mathrm{~mm}$ long. Pollinia 2, oblong. Fruit capsule, turgid, 7-9 mm long, broadly-elliptic. (Fig. 1a-k).

Distribution: India (Jammu \& Kashmir to Arunachal Pradesh), China, Pakistan, Nepal, Bhutan, Myanmar,

DOI: http://dx.doi.org/10.11609/JoTT.o2828.4601-3

Editor: Anonymity requested.

Date of publication: 26 July 2013 (online \& print)

Manuscript details: Ms \# 02828 | Received 09 June 2011 | Final received 15 July 2013 | Finally accepted 16 July 2013

Citation: Verma, J., K. Thakur \& S.P. Vij (2013). On the occurrence of an interesting leafless orchid Neottia listeroides Lindl. in Himachal Pradesh, northwestern Himalaya, India. Journal of Threatened Taxa 5(11): 4601-4603; http://dx.doi.org/10.11609/JoTT.02828.4601-3

Copyright: (c) Verma et al. 2013. Creative Commons Attribution 3.0 Unported License. JoTT allows unrestricted use of this article in any medium, reproduction and distribution by providing adequate credit to the authors and the source of publication.

Funding: The financial support from Government of India, Ministry of Environment \& Forests (AICOPTAX), is thankfully acknowledged.

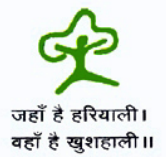

Competing Interest: None. 
Tibet. In Himachal Pradesh the species is distributed in Shimla (Narkanda-Hattu, Sarain-Choordhar), Kullu (Kothi), Kangra (above Polang), and Lahul at an altitude of 2,000-3,500 m.

Flowering: July-August.

Fruiting: August-September.

Ecology: The plants were growing singly or in groups of 3-10 individuals on moist, shady and humus rich localities in conifer-oak forests (Image 1). The species is not of common occurrence in the state and therefore only one specimen (Orch 236) was collected and deposited at Herbarium, Panjab University (PAN), Chandigarh, India.

Threats and Conservation: A large proportion of orchid habitats (forests/grasslands) in Himachal Pradesh have lost their quality due to expanded agricultural and other developmental activities. Large scale exploitation of forests for tourism related activities has detrimentally affected the delicately balanced ecological equilibrium; even littering and trampling are enough to impair the habitats. This species is vulnerable to frequent land slips, grazing, and fodder and fuel wood collection activities. The orchids are inherently slow growers and due to their nutritional complexities (which are relatively more complex in leafless species) they germinate poorly in nature. In N. listeroides, though the green flowers and young stems help plants in performing photosynthesis,

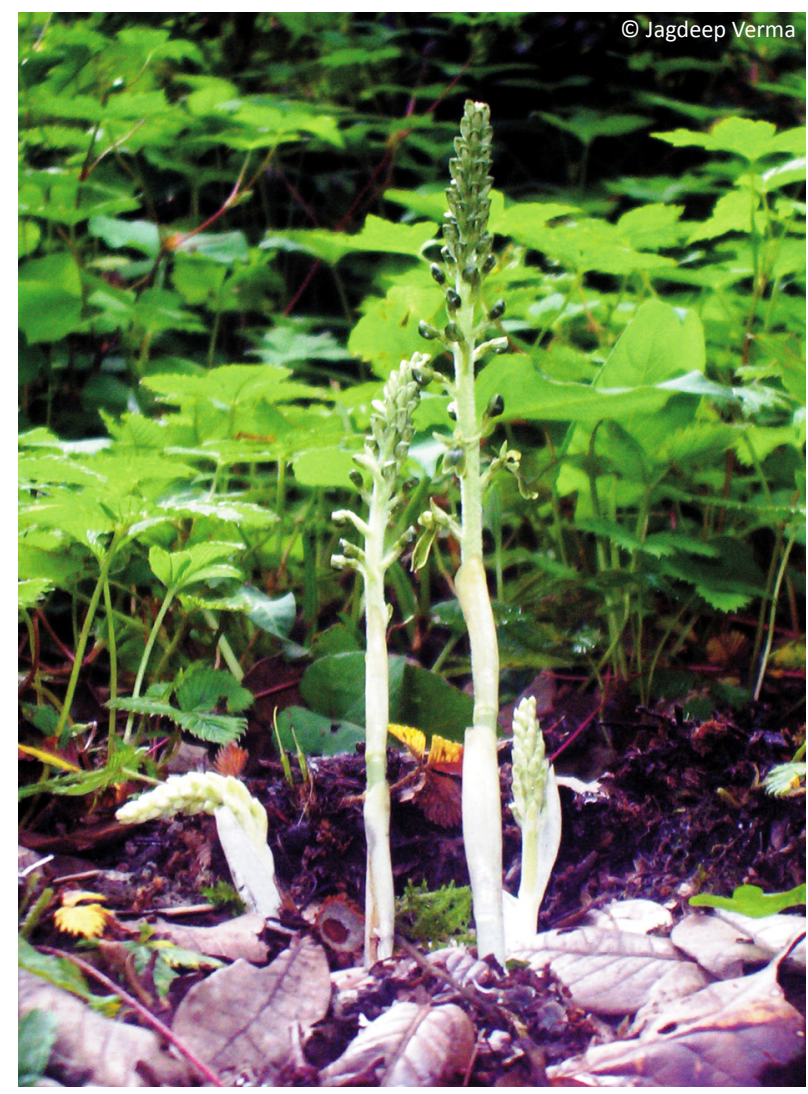

Image 1. Neottia listeroides Lindl. Plants growing in Oak-pine forest at Churdhar.

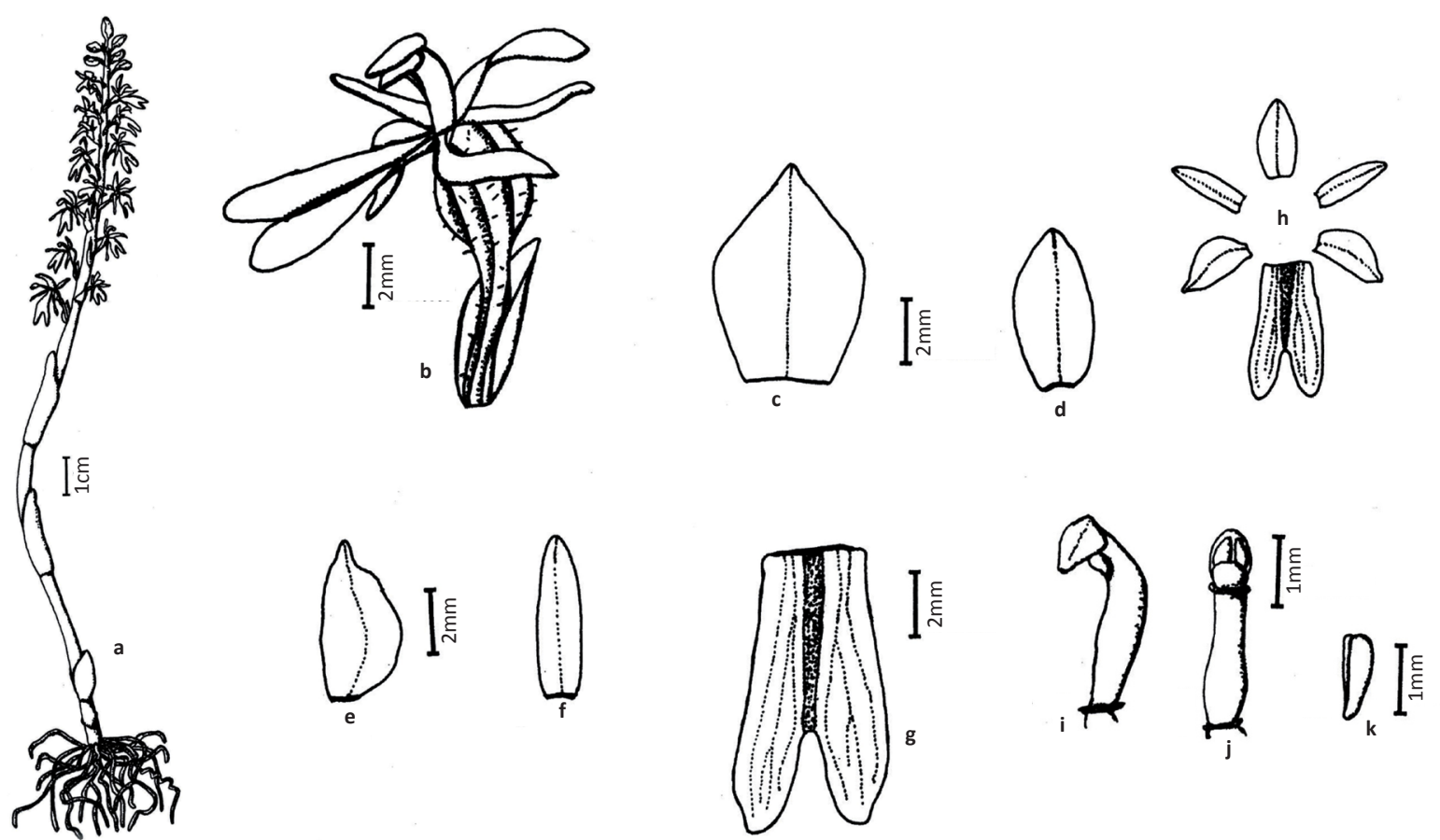

Figure 1 a-k. Neottia listeroides Lindl. a - A plant showing habit (note the highly clustered roots); b - flower; c - floral bract; $d$ - dorsal sepal; e - lateral sepal; f - petal; $\mathrm{g}$ - lip; $\mathrm{h}$ - floral parts spread (not to scale); i-j - column; k - pollinia. 
the leafless species are generally believed to obtain nutrients from a mycorrhizal fungus that is attached to a photosynthetic host plant. Proactive measures should be taken for conservation of such orchid species and their habitats.

\section{REFERENCES}

Deva, S. \& H.B. Naithani (1986). The Orchid Flora of North West Himalaya. Print and Media Associates, New Delhi, 71pp.

Jalal, J.S., P. Kumar, G.S. Rawat \& Y.P.S. Pangtey (2008). Orchidaceae, Uttarakhand, Western Himalaya, India. Check List 4(3): 304-320.

Xinqi, C., S.W. Gale \& P.J. Cribb (2009). Neottia Guettard. Flora of China 25: 184-195. 